\title{
Germ cell specification and ovary structure in the rotifer Brachionus plicatilis
}

James M Smith ${ }^{1}$, Andrew G Cridge ${ }^{2}$, Peter K Dearden ${ }^{1 *}$

\begin{abstract}
Background: The segregation of the germline from somatic tissues is an essential process in the development of all animals. Specification of the primordial germ cells (PGCs) takes place via different strategies across animal phyla; either specified early in embryogenesis by the inheritance of maternal determinants in the cytoplasm of the oocyte ('preformation') or selected later in embryonic development from undifferentiated precursors by a localized inductive signal ('epigenesis'). Here we investigate the specification and development of the germ cells in the rotifer Brachionus plicatilis, a member of the poorly-characterized superphyla Lophotrochozoa, by isolating the Brachionus homologues of the conserved germ cell markers vasa and nanos, and examining their expression using in situ hybridization.

Results: Bpvasa and Bpnos RNA expression have very similar distributions in the Brachionus ovary, showing ubiquitous expression in the vitellarium, with higher levels in the putative germ cell cluster. Bpvas RNA expression is present in freshly laid eggs, remaining ubiquitous in embryos until at least the 96 cell stage after which expression narrows to a small cluster of cells at the putative posterior of the embryo, consistent with the developing ovary. Bpnos RNA expression is also present in just-laid eggs but expression is much reduced by the four-cell stage and absent by the 16-cell stage. Shortly before hatching of the juvenile rotifer from the egg, Bpnos RNA expression is re-activated, located in a subset of posterior cells similar to those expressing Bpvas at the same stage.
\end{abstract}

Conclusions: The observed expression of vasa and nanos in the developing B. plicatilis embryo implies an epigenetic origin of primordial germ cells in Rotifer.

\section{Background}

The segregation of the germline from somatic tissues is an essential process in the development of all animals. Despite this, specification of the progenitors of the germline, the primordial germ cells (PGCs), takes place via two broadly different strategies across animal phyla (reviewed in [1]). Germ cells can be specified early in embryogenesis by the inheritance of maternal determinants inherited in the cytoplasm of the oocyte ('preformation'), as in Drosophila, Danio rerio, Xenopus laevis and Caenorhabditis elegans. Alternately, as in the mouse, germ cells can be selected later in the embryonic development from undifferentiated precursors by a

\footnotetext{
* Correspondence: peter.dearden@otago.ac.nz

'Laboratory for Evolution and Development, Genetics Otago and the National Research Centre for Growth and Development, Biochemistry Department, University of Otago, PO Box 56, Dunedin, Aotearoa-New Zealand
}

(c) 2010 Smith et al; licensee BioMed Central Ltd. This is an Open Access article distributed under the terms of the Creative Commons Attribution License (http://creativecommons.org/licenses/by/2.0), which permits unrestricted use, distribution, and reproduction in any medium, provided the original work is properly cited. preformation, epigenesis is the more prevalent mechanism for PGC specification across animal phyla. This, along with the prevalence of epigenesis for germline specification in basal metazoans, implicates epigenesis as the ancestral mechanism of germ line specification in animals [2]. It should be noted, however, that the majority of studies of PGC specification are from two of the three animal super-phyla as determined by modern phylogenetics [3], namely the Ecdysozoa and the Deuterostoma. Relatively little is known about how the germline is specified in the Lophotrochozoa, which is the largest (containing more than half of all animal phyla [4]) and exhibits the greatest diversity in body plans of the three superphyletic groups of animals.

Despite these broadly different mechanisms for the specification of the germline, some of the proteins ity of genetic model organisms specify germ cells by 
involved in PGC specification are highly conserved and expressed in germ cells whether they form by epigenesis or preformation. PGC specification can thus be reliably tracked by the expression of germline markers such as the products of the vasa and nanos genes (reviewed in [1]).

vasa encodes an adenosine triphosphate (ATP)-dependent RNA helicase that is a member of the DEAD box protein family [5,6]. In Drosophila, in which vasa expression and function has been best characterized, Vasa protein is associated with polar granules [7], electron-dense structures within the oocyte pole plasm which give rise to the germline, and is essential for formation of the pole plasm and progession of oogenesis. On a molecular level, Vasa acts as a translational regulator of the oocyte-specific maternal mRNAs, such as gurken, through binding of the translation factor eIF5B [8] and is also required for the localization of nanos RNA [9]. Throughout animals vasa is expressed in germ cell progenitors and other stem cell types [1], regardless of the mechanism of germline specification. In mice, the best characterized species that undergoes epigenesis, vasa homologues are expressed in PGCs and are required for development of the male germline [10]. Vasa RNA and protein have been found associated with PGC specification and development in many species across the metazoa [11-20]. While the precise molecular function of vasa across evolution remains elusive, the broad conservation of germline components with which vasa interacts in Drosophila suggests that the mode of action of vasa is conserved across germline development in animals.

nanos genes have been implicated in specification of both germline and somatic cell fate, although their roles in the formation and/or maintenance of PGCs are more broadly conserved [21] and are considered to be their ancestral function. Nanos proteins contain two highly conserved $\mathrm{C}$-terminal $\mathrm{CCHC}$ zinc finger domains and act as translational inhibitors [22], repressing somatic cell fate in the developing germline in Drosophila. Roles for Nanos in the development of somatic tissues have been identified in insects, most notably in establishing embryonic polarity [22], and, more recently, in a small number of Lophotrochozoan phyla [18,23-25] where they have been implicated in specification of somatic cell lineages such as mesoderm.

In this study we examine the expression of vasa and nanos in germline development of the monogonont rotifer Brachionus plicatilis. The rotifera are a diverse nonsegmented aquatic lophotrochozoan phyla containing two major branches, the bdelloids and the monogononts. Bdelloids are obligately asexual while monogononts are facultatively sexual, producing either amictic (diploid) or mictic (haploid) offspring. The ovary of the monogonont rotifer consists of a syncytial vitellarium connected via an oviduct to a germarium containing primordial germ cells. Cytoplasmic bridges connect developing oocytes to the vitellarium, through which maternal factors synthesized in the vitellarium are transported [26]. Morphological investigations have suggested rotifer PGCs are produced by a preformation mechanism ([27]; referenced in [1]), though this has yet to be confirmed by molecular analyses.

\section{Results}

\section{Brachionus ovary anatomy and the origin of oocytes}

The ovary of Brachionus females lies in the posterior half of the animal and is regulated by nutritional status. Starved rotifers have reduced ovaries that condense towards the midline of the animal (Figure 1A and 1B). Fully fed, reproductively active rotifers have large ovaries (Figure 1C-E) with clearly visible oocytes. The Brachionus ovary is made up of three major populations of cells (Figure 1F-I). The vitellarium, a large, nutritionally-sensitive structure, is thought to be syncytial [26]. The vitellarium is distinguished, in well-fed animals, by large elongate nuclei. Attached to the side of the vitellarium is typically the developing oocyte, a large cell with a small rounded nucleus. This cell, the oocyte, expands in volume over time, often growing to such an extent before laying that it deforms the structure of the ovary, displacing the nuclei of the vitellarium, as well as pushing other internal organs of the rotifer towards the head. The developing oocyte always forms on one side of the ovary, anterior and to the left when the rotifer is viewed with ovary uppermost (that is, lying over the gut). The adjoining region of the vitellarium also harbours a population of small cells (usually 20-22 in newly hatched adult rotifers), arranged in rows, with small rounded nuclei, that we, and others $[26,28]$, take to be the precursors of the oocyte; the PGCs.

The cytoplasm of the developing oocyte and that of the vitellarium is granulose, probably due to lipid droplets, when viewed under differential interference contrast (DIC) or phase contrast optics. These droplets are concentrated in the oocyte (Figure 1F-I). We interpret this to mean that these droplets are synthesized in the vitellarium and are then transported into the developing oocyte via cytoplasmic bridges.

Brachionus oocytes express a factor that reacts strongly with $\mathrm{DAB}$ and hydrogen peroxide, staining darkly (Figure 1J-L). It is not clear what this factor is, other than it has putative peroxidase activity, but it is distributed in an interesting pattern suggesting that it may too be transported into the oocyte. Peroxidase-substrate-positive granules are distributed sparsely throughout the cytoplasm of the vitellarium (arrow in Figure $1 \mathrm{~J})$, increasing in density nearest the developing oocyte, 

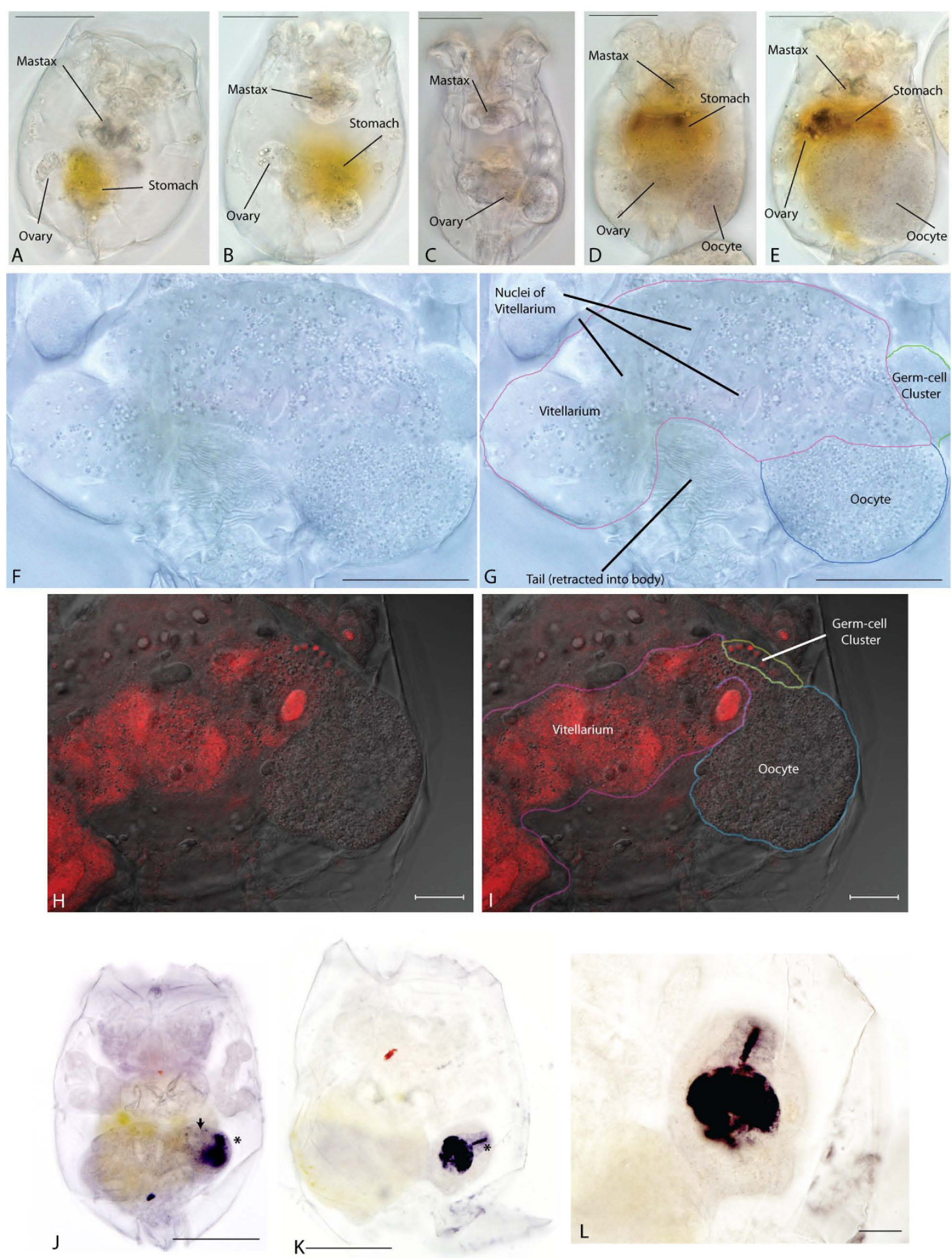

Figure 1 Structure of the Brachionus plicatilis ovary. Light and fluorescent images of the Brachionus ovary. (A-E) Differential interference contrast (DIC) images of whole Brachionus indicating the ovary and other morphological structures. Scale bars indicate $100 \mu \mathrm{m}$. Rotifer range from starved adult individuals with greatly reduced ovaries (A) to normal individuals (C), to those with a developing oocyte (D) to those with a large oocyte deforming other structures (E). ( $F$ and G) Higher magnification image of a Brachionus ovary (annotated in G) under DIC optics showing the structures of the vitellarium, germ cell cluster and oocyte. Scale bars represent $50 \mu \mathrm{m}$. Note: the granules/lipid droplets in the vitellarium and their concentration in the oocyte. ( $\mathrm{H}$ and I) High magnification mixed confocal/phase contrast image of a Brachionus ovary stained with propidium iodide (red) for nuclei (annotated in I). All of the cell types of the ovary are visible. Scale bars represent $50 \mu \mathrm{m}(\mathrm{J}-\mathrm{L}$ ) Expression of compounds reactive to $\mathrm{DAB}$ and $\mathrm{H}_{2} \mathrm{O}_{2}$, producing intense black staining. Staining is in the oocyte and in a tube (asterisks in $\mathrm{J}$ and $\mathrm{K})$, passing near the germ-cells, that appears to connect the vitellarium with the developing oocyte. Granular staining is also seen in the vitellarium (arrowhead in J) Scale bars in J and $\mathrm{K}$ are $100 \mu \mathrm{m}, 50 \mu \mathrm{m}$ in L. 
and staining is particularly intense in a short tube or column leading to the developing oocyte from the vitellarium, flanked by the PGCs (asterisks in Figures 1J and $1 \mathrm{~K})$. The cytoplasm of the oocyte itself also stains intensely for this factor. This evidence strongly implies that the vitellarium, with its large active nuclei, makes a number of factors - both RNA, protein and lipid droplets - that are transported into the cytoplasm of the maturing oocyte and it may be this accumulation of maternal products transported from the vitellarium that swells the egg, eventually causing deformation of the vitellarium, before the egg is finally released.

\section{Identification of Rotifer vasa and nanos}

In order to better describe the rotifer ovary and the origins of germ cells during development we isolated orthologues of vasa and nanos, both conserved germ cell markers.
Brachionus sequences similar to vasa were identified and assembled from sequencing of degenerate PCR fragments, published EST data and a pyrosequencing transcriptome sequencing project carried out using 454 technology. Sequences similar to vasa were assembled using CAP3 and predicted protein coding sequences obtained. By Blast analysis, these identified sequences showed similarities to Vasa proteins from other lophotrochozoan species. Bayesian phylogenetic analysis using Vasa protein sequences as well as protein sequences similar to the closest DEAD box RNA helicase genes identified in our 454 transcriptome data (Figure 2A) indicates that this Brachionus vasa-like sequence clusters with high posterior probability with other metazoan Vasa proteins, to the exclusion of closely related DEAD box sequences. This implies that the sequence we have identified is a Brachionus orthologue of Vasa. We designate the gene encoding this protein Bpvasa (Bpvas).

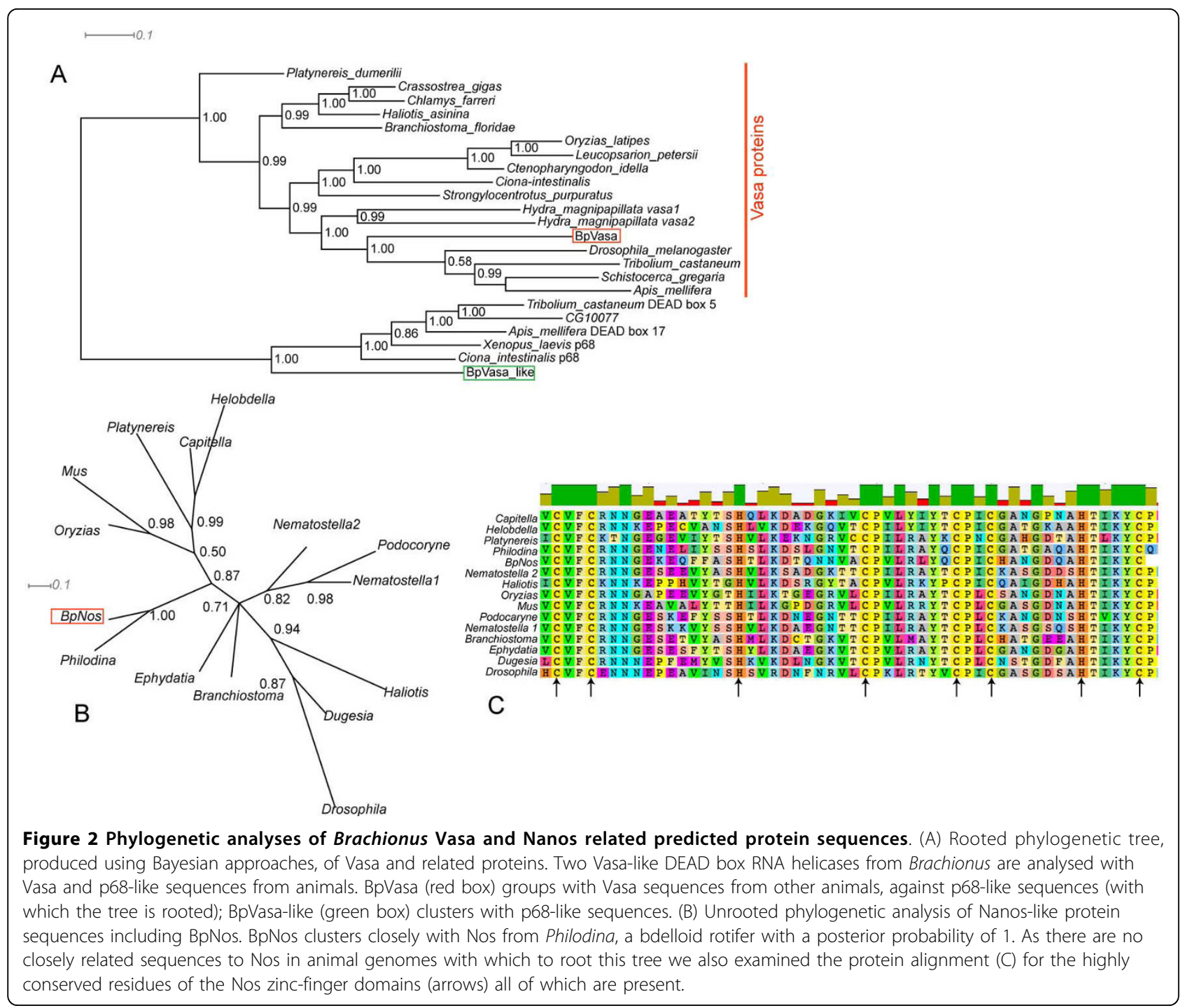






nanos genes encode zinc finger transcription factors with a highly conserved DNA binding domain. Blast searches of available Brachionus sequence data, as well as a fragment of sequence obtained via degenerate PCR, identified a small number of sequences with similarity to nanos. These sequences were assembled using CAP3 and a predicted protein coding sequence obtained. Alignment of this protein sequence with those of other metazoan Nanos proteins (Figure 2C) showed our putative nanos homologue encoded a strongly conserved zinc finger binding domain with two characteristic CCHC motifs (arrowed). Similarity outside of this region was limited (data not shown) and so Bayesian phylogenetic analysis was performed on an alignment of just the zinc finger domain. The resulting consensus tree (Figure 2B) shows that this Brachionus sequence is very similar to other Nanos proteins and clusters most closely with Nanos protein from the Bdelloid rotifer Philodina. This analysis, and the conserved residues, strongly indicates that we have identified a Brachionus homologue of nanos. We designate the gene encoding this protein Bpnanos (Bpnos).

\section{Gene expression in the Rotifer ovary}

As vasa and nos are conserved germ cell markers we examined the distribution of RNA expression of the Brachionus orthologues of these genes in the adult ovary.

Bpvas RNA is expressed in all the cell types of the ovary, but at different levels (Figure 3). Expression is weak in the vitellarium but ubiquitously distributed. Expression is higher in the putative germ-cell cluster. As the oocyte begins to develop (Figure 3A-C, close-up in 3D) Bpvas RNA comes to be most highly expressed in the oocyte with very high levels present in oocytes that are about to be released. No Bpvas expression is seen in any other tissue of adult rotifer.

Bpnos RNA expression has a very similar distribution in the ovary to that of Bpvas (Figure 4). Bpnos RNA is present ubiquitously in the vitellarium with higher levels in the putative germ-cell cluster. As the oocyte develops and matures Bpnos RNA expression becomes stronger in the oocyte and germ cell cluster (Figure 4B-D). No Bpnos RNA expression is seen in any other adult rotifer tissue. Control staining with sense RNA probes from




Bpnos or Bpvas shows no staining in adult or embryonic tissues (data not shown). In-situ hybridization using the method described here using probes for Brachionus pax6 RNA gives the same expression pattern as that reported in [29] (data not shown).

\section{vasa and nanos expression in the developing Rotifer embryo}

In order to understand the origins of germ cells in $\mathrm{Bra}$ chionus we also examined the distribution of Bpnos and Bpvas RNA in developing embryos. Bpvas RNA expression remains present in just-laid, 1 cell embryos; probably persisting maternal RNA (Figure 5A). Expression remains ubiquitous in embryos (Figure 5A-E) until at least 96 cells (as judged by nuclear staining; Figure 5E) are present. After this stage, expression narrows to a small cluster of two to six cells at one end of the embryo (Figure 5F-H). This narrowing appears to be due to loss of RNA expression from the majority of cells (Figure 5F). As development continues this cluster of Bpvas positive cells remains located towards one end of the embryo and, as morphology becomes apparent, it is clear that this is the posterior end (Figure 5I). As the corona and mastax become visible just before hatching, Bpvas expression is present in a dumb-bell shaped domain in the posterior in a region consistent with the developing ovary (Figure 5J).

Bpnos RNA expression is also present in just-laid eggs (Figure $5 \mathrm{~K}$ ) but expression is significantly reduced by the two-cell stage (Figure $5 \mathrm{~L}$ ) and absent by the 16cell stage. Bpnos RNA expression is not present in the animal until just before hatching; the RNA is located in a dumb-bell shaped patch of cells, similar to that seen for Bpvas staining, in the posterior regions of the embryo, probably representng the developing ovary (Figure $5 \mathrm{~N}$ ).

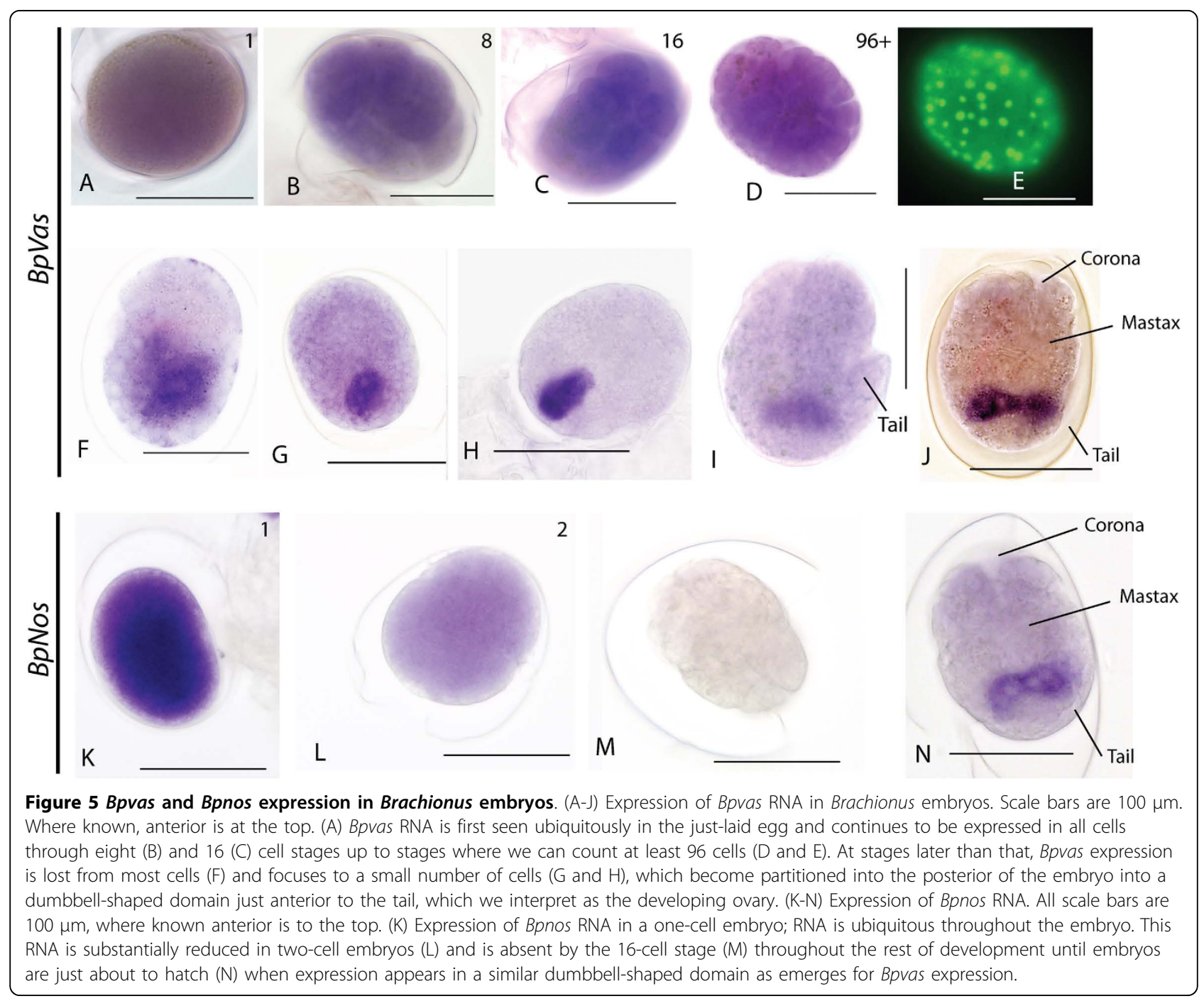




\section{Discussion}

\section{Germ cell development in Brachionus plicatilis}

The expression of vasa and nos in the developing B. plicatilis embryo appears consistent with an origin of primordial germ cells via epigenesis in rotifer. There exists no specific subpopulation of embryonic cells showing the expression of both factors from early in development, nor is there any evidence for the germline-specific localization of Bpvas or Bpnos RNA in the egg or embryo until later stages. Both of these findings indicate that preformation of PGCs is unlikely in Brachionus; Bpvas expression is ubiquitous throughout the early embryo, while Bpnos expression disappears from the embryo beyond the four-cell stage and only reappears beyond the 96-cell stage in a posterior cluster of cells which we take to be the same subset of cells marked by Bpvas expression. The observed expression pattern of Bpvasa RNA in B. plicatilis, whereby the broad maternal distribution of expression throughout the early embryo becomes restricted to putative germline precursors as development progresses, is consistent with that in annelid Lophotrochozoans such as Platynereis [18], Capitella [23] and Tubifex [30].

It would seem probable that some form of inductive event or process maintains Bpvas expression in these cells as it is lost from the rest of the embryo and/or induces the expression of Bpnos in the same cells (it is not possible at present to dissect which, if either, of these events precedes the other). Based on the maintenance of Bpvas expression throughout the embryo up to this point, it would seem that all cells retain the ability to become PGCs, though only a subset do, presumably under the influence of some form of positionally specified epigenetic signal.

Our observation of an origin for PGCs via epigenesis in rotifers contrasts with the historical literature, which proposes PGCs are preformed prior to gastrulation ([27]; referenced in [1]). It should be noted, however, that these studies were based on morphological characterization of cell types by light microscopy. This is the first experimental investigation of rotifer PGC formation by way of molecular evidence, in particular expression profiling of conserved germ cell markers during embryogenesis. At this stage, we cannot entirely rule out preformation as a mechanism for forming PGCs in rotifer, due to the possibility that post-translational regulation could provide a means by which Vasa and/or Nos proteins could be localized to specific cell types within the oocyte throughout embryonic development - despite the the ubiquitous mRNA distribution of vasa and the absence of nos transcripts at these stages. Post-translational regulation of proteins involved in oogenesis is a recurring theme in Drosophila (reviewed in [9]). Despite this we see no direct evidence to support preformation of PGCs in this rotifer. Our findings are consistent with the observation that epigenesis is the most common and likely to be the ancestral means of generating germ cells amongst the Lophotrochozoa [1], with only a subset of annelid, mollusc and platyhelminth species reported to produce PGCs via preformation.

\section{Absence of somatic cell expression of vasa and nos}

Expression of both Bpvas and Bpnos appears largely absent from somatic cell lineages in late embryonic and adult rotifer, save for expression in the vitellarium of the ovary associated with 'loading' of the developing oocyte with maternal transcripts. Indeed, Bpnos transcripts are absent throughout the development of the rotifer, other than very early in embryonic development, (presumably maternally derived) and in developing PGCs of the ovary. This is in contrast to several Lophotrochozoan species in which nos is expressed in somatic cell lineages and has roles in early embryonic patterning, predominantly of mesoderm [18,23-25]. Rotifer are known to differ from other Lophotrochozoan phyla in key elements of early embryogenesis; while rotifer are said to exhibit 'modified' spiral cleavage [31] they lack the heavily stereotyped early cell division pattern of canonical spiral cleavage (Spiralia), such that characteristic cells of spiral cleavage are not evident [29]. For instance, immunohistochemistry for activated MAPK (mitogen-activated protein kinase) which marks the $4 \mathrm{~d}$ micromere, the mesodermal organizer in spiralian lophotrochozoans, [32] fails to identify an equivalent structure in rotifer (data not shown), which suggests that mesodermal specification may take place via alternative mechanisms than those identified in spiralian phyla.

The expression patterns of Bpvas and Bpnos, as well as the localization of lipid droplets/vesicles and reactivity to $D A B$, suggests that the vitellarium acts to nutritionally provision the oocyte. The observation of Brachionus oocytes expressing a factor that reacts strongly to peroxidase substrates is interesting in light of the report of expression of a plant-like peroxidase gene in Hydra oogenesis [33], although no homologue to this Hydra gene (HvAPX1) was detected in our Brachionus transcriptome sequence (data not shown). Our observation that the size of the rotifer ovary is responsive to nutrition suggests that it is a highly metabolically active tissue that, in adverse conditions, is too expensive to maintain. It is possible, however, that is responding to more subtle changes in diet, such as macronutrient status [34] or amino-acid balance [35]. The vitellarium transports both RNA and protein in the oocyte (as well as the lipid vesicles) and appears to maintain a 
cytoplasmic bridge to the oocyte until the egg is ejected. None of the expression patterns of RNA we have examined suggests that the vitellarium acts to pattern the early egg, although the asymmetry in the localization of the egg, with respect to the vitellarium and ovary in the adult, implies that the provision of patterning data is possible.

We have described, for the first time in molecular detail, the activity of the Brachionus ovary and the localization and formation of germ cells by epigenesis in the developing Brachionus embryo. How the expression of Bpvas RNA is constrained to a few cells at the putative point of germ cell specification, and how these cells then come to be recruited to the ovary remains to be discovered. Indeed little is known about the molecular, or even morphological, aspects of development in Rotifer but Brachionus, with its fast generation time and accessible embryos, is likely to be an excellent model system for studying development in this phylum.

\section{Methods}

\section{Rotifer culture}

B. plicatilis Nevada (Additional File 1) rotifers were cultured at $25^{\circ} \mathrm{C}$ in conical flasks in F2 media [36,37] made with Instant Ocean artificial seawater (Aquarium Systems, OH, USA) and fed either Duniella sp. microalgae or Culture Selco High Density commercial rotifer feedstock (2g/L; INVE Aquaculture, UT, USA).

\section{Identification of $B$. plicatilis vasa and nanos sequences} Fragments of B. plicatilis vasa and nos genes were initially amplified from cDNA by degenerate polymerase chain reaction (PCR). Rotifers were concentrated by centrifugation, total RNA was extracted using Trizol reagent (Invitrogen) and first-strand cDNA synthesis carried out with Superscript III (Invitrogen, CA, USA) using an oligo-dT primer. Degenerate PCR primers were used to amplify the conserved domains of the vasa and nanos genes from $B$. plicatilis $\mathrm{cDNA}$. The sequences of primers used were: vasa-F2 5'-GA(A/G)AAICCCAT(A/G)TCIA (A/G)CAT-3' and vasa-F2 5'-CAGACGGGITCIGGIAA (A/G)AC-3' [38]; nanos1 5'-CGGAATTCCGTG(C/T) $\operatorname{GTITT}(\mathrm{C} / \mathrm{T}) \mathrm{TG}(\mathrm{T} / \mathrm{C})(\mathrm{G} / \mathrm{A} / \mathrm{C}) \operatorname{AGIAA}(\mathrm{C} / \mathrm{T}) \mathrm{AA}-3^{\prime}$ and nanos2 CGGGATCCCGGG(G/A)CA(G/A)TA(T/C) TTIA(T/C)IGT(GA)TG-3' [39]. PCR products were cloned into pCRII-TOPO (Invitrogen) for transformation into $E$. coli, sequencing and the maintenance of clones.

A modified form of $3^{\prime}$ RACE was used to amplify an additional 3 ' sequence of B. plicatilis nanos sufficient for it to be used as a template for in situ hybridization probe synthesis. Rotifer cDNAs were directionally cloned into the Invitrogen CloneMiner cDNA Library Construction system, pooled library plasmid DNA from which was used as a template for PCR amplification using the nanos $5^{\prime}$ primer and a vector reverse primer. This PCR product was cloned and sequenced. A new $3^{\prime}$ primer was designed in order to complement the very $3^{\prime}$ end of the Bpnos transcript, which was used in conjunction with the $5^{\prime}$ primer in order to amplify, clone and sequence this fragment.

Sequences obtained were subsequently compared with ESTs made available in the National Center for Biotechnology Information databases from B. plicatilis EST sequencing projects $[40,41]$ to confirm the integrity and continuity of sequences obtained by degenerate PCR. Additionally, sequences corresponding to vasa and nanos were subsequently identified from a large transcriptome sequencing project undertaken using 454 pyrosequencing technology (Smith, Benton, Hyink and Dearden, unpublished data). Sequences were assembled using CAP3 [42] and similarity to known vasa and nos sequences assessed using Blastx [43].

\section{Phylogenetic analysis}

Phylogenetic analysis was carried out on predicted protein sequences for Vasa and Nanos aligned using ClustalX [44]. Bayesian phylogenetic analysis was carried out with the MrBayes software [45], using either the WAG (Vasa) [46] or BLOSUM (Nanos) models of amino acid substitution - after being identified as the appropriate model after initial experiments using mixed models. Twenty-five per cent of the initial trees were discarded as 'burnin' and the resulting consensus tree visualized using Dendroscope [47].

\section{In situ hybridization}

Rotifers were harvested from culture medium by being sieved through a $74 \mu \mathrm{m}$ filter (Sigma CD1 cell culture sieves). Rotifers were then resuspended in artificial seawater and relaxed with $10 \%$ ethanol for $5 \mathrm{~min}$. Formaldehyde was then added to $4 \%$ and the rotifer fixed for 10-15 min. Rotifers were then washed twice in PTw (phosphate buffered saline $+0.1 \%$ Tween 20 ), transferred into a glass test tube and sonicated in a Benchtop Ultrasonic Cleaner (Model 80T, Soniclean, Thebarton, South Australia, http://www.soniclean.com.au; 60W pulse swept power output, fixed frequency of $33+/-3$ $\mathrm{kHz}$ ) for 15-30 s. Rotifers were then allowed to settle and transferred to fresh PTw and incubated with $10 \mu \mathrm{g} /$ $\mu \mathrm{L}$ proteinase $\mathrm{K}$ for $10-15 \mathrm{~min}$ at room temperature. The rotifers were washed in PTw twice, formaldehyde was added to $4 \%$ and then they were incubated at room temperature for $15 \mathrm{~min}$. The tissue was then washed six times in PTw, transferred to hybridization buffer (50\% formamide, $4 \times$ standard saline citrate $(\mathrm{SSC}), 1 \times$ Denhardt's solution, $250 \mu \mathrm{g} / \mathrm{mL}$ yeast total RNA, $250 \mu \mathrm{g} / \mathrm{mL}$ boiled salmon sperm or calf thymus DNA, $50 \mu \mathrm{g} / \mathrm{mL}$ heparin (Sigma), 0.1\% Tween 20,5\% dextran sulphate) 
and incubated for $2-3 \mathrm{~h}$ at $52^{\circ}$. Typically, hundreds of rotifer adults and embryos were used in each in-situ hybridization reaction in order to provide as broad a developmental time-course as possible.

Digoxigenin (DIG) labelled RNA probes for in situ hybridization were prepared as described in [48]. Two doses of $4 \mu \mathrm{L}$ probe were digested in an equal volume of carbonate buffer at $60^{\circ}$ for up to $30 \mathrm{~min}$ (depending on the length of the probe). One hundred microlitres of hybridization buffer was then added to the probe. The hybridization buffer was removed from the rotifers and replaced with the digested probe solution and the mixture incubated overnight at $56^{\circ}$. Rotifers were then washed seven times over 24 hours in $50 \%$ formamide, $2 \times$ SSC, $0.1 \%$ Tween 20 at $56^{\circ}$.

Rotifers were transferred into $\mathrm{PTw}$, rinsed three times and incubated in $\mathrm{PTw}+0.1 \% \mathrm{w} / \mathrm{v}$ bovine serum albumin (BSA) for $15 \mathrm{~min}$. The DIG hapten was detected using a 1:500 dilution of anti-DIG-alkaline phosphatase antibodies (Roche Applied Science, IN, USA) in $\mathrm{PTw}+0.1 \%$ BSA for $90 \mathrm{~min}$ at room temperature. The antibody solution was removed and the rotifers washed six times in PTw over $2 \mathrm{~h}$. Rotifers were washed twice in alkaline phosphatase (AP) staining buffer $(100 \mathrm{mM}$ Tris $\mathrm{pH} 9.5,100 \mathrm{mM} \mathrm{NaCl}, 50$ $\mathrm{mM} \mathrm{MgCl} 2,0.1 \%$ Tween 20) and AP activity detected using $4.5 \mu \mathrm{L}$ nitro blue tetrazolium chloride $(75 \mathrm{mg} /$ $\mathrm{mL}$ in dimethylformamide (DMF), Roche Applied Science) and 3.5 $\mu \mathrm{L}$ 5-bromo-4-chloro-3-indolyl-phosphate $(50 \mathrm{mg} / \mathrm{mL}$ in DMF, Roche Applied Science) in AP buffer. Staining was monitored under a stereomicroscope and the tissues washed and transferred to methanol for de-staining when clear staining was observed. Tissues were rehydrated after the methanol wash, counterstained by incubation for $1 \mathrm{~h}$ in PTx containing either 1:1000 ProLong ${ }^{\odot}$ Gold antifade reagent with DAPI or $1 \mu \mathrm{M}$ YOYO-1 (Invitrogen), cleared and mounted in 70\% glycerol and examined under an Olympus BX61 compound microscope.

\section{Histochemistry}

Rotifers were harvested, fixed and sonicated as described above for in situ hybridization. Rotifers were placed in $\mathrm{DAB}$ staining solution [49] $+0.8 \% \mathrm{NiCl}_{2}$. After 5 min pre-incubation $\mathrm{H}_{2} \mathrm{O}_{2}$ was added to $0.006 \%$ and the staining was monitored under a dissecting microscope. Staining was stopped by washing in PTx and the specimens were counterstained by incubation for $1 \mathrm{~h}$ in PTx containing either 1:1000 ProLong ${ }^{\circ}$ Gold antifade reagent with DAPI, $1 \mathrm{uM}$ propidium iodide or $1 \mu \mathrm{M}$ YOYO-1 (Invitrogen). Rotifers were cleared and mounted in $70 \%$ glycerol and examined on an Olympus BX61 microscope.

\section{Additional material}

Additional file 1: Supplemental Figure 1. Unrooted Phylogram of Brachionus $16 \mathrm{~S}$ ribosomal sequences. Three $16 \mathrm{~S}$ sequences from the stock of rotifers used in this experiment cluster with Brachionus plicatilis species against other Brachionus species and Euchlanis dilatata. Two Brachionus species, one an isolate from Nevada with no species name in the database, and B. manjavacas, fall within the plicatilis clade. The rotifers used in this study cluster most closely with the Nevada isolate of B. plicatilis. Phylogram was constructed with MrBayes using the 4 by 4 model of nucleotide substitution. $25 \%$ of the initial trees were discarded as 'burnin' and the resulting consensus tree visualized using Dendroscope [47].

\section{Abbreviations}

AP: alkaline phosphatase; BSA: bovine serum albumin; DIC: differential interference contrast; DIG: digoxigenin; EST: expressed sequence tag; MAPK: mitogen-activated protein kinase; PCR: polymerase chain reaction; PGC: primordial germ cells; PTw: phosphaste buffered saline plus Tween.

\section{Acknowledgements}

The authors would like to thank M J Wilson, E J Duncan, O Hyink, S Morgan and $\mathrm{N}$ Kenny for their critical reading of the manuscript. The authors also wish to thank three anonymous reviewers whose comments greatly improved the manuscript. The research was funded via a Royal Society of New Zealand Marsden Grant (UOO0602) to PKD.

\section{Author details}

${ }^{1}$ Laboratory for Evolution and Development, Genetics Otago and the National Research Centre for Growth and Development, Biochemistry Department, University of Otago, PO Box 56, Dunedin, Aotearoa-New Zealand. ${ }^{2}$ Institute of Natural Sciences, Massey University Albany Campus, Private Bag 102904, North Shore MSC, Auckland, Aotearoa-New Zealand.

\section{Authors' contributions}

JMS carried out some of the experiments, including molecular cloning, and contributed to drafting of the paper. AGC developed the techniques used in these analyses. PKD designed the study, carried out in-situ hybridization, immunohistochemistry and phylogenetics and contributed to the drafting the paper.

\section{Competing interests}

The authors declare that they have no competing interests

Received: 8 December 2009 Accepted: 2 August 2010

Published: 2 August 2010

\section{References}

1. Extavour CG, Akam M: Mechanisms of germ cell specification across the metazoans: epigenesis and preformation. Development 2003, 130:5869-5884.

2. Extavour $\mathrm{CG}$, Pang $\mathrm{K}$, Matus DQ, Martindale $\mathrm{MQ}$ : vasa and nanos expression patterns in a sea anemone and the evolution of bilaterian germ cell specification mechanisms. Evol Dev 2005, 7:201-215.

3. Dunn CW, Hejnol A, Matus DQ, Pang K, Browne WE, Smith SA, Seaver E, Rouse GW, Obst M, Edgecombe GD, Sørensen MV, Haddock SH, SchmidtRhaesa A, Okusu A, Kristensen RM, Wheeler WC, Martindale MQ, Giribet G: Broad phylogenomic sampling improves resolution of the animal tree of life. Nature 2008, 452:745-749.

4. Giribet G: Assembling the lophotrochozoan (=spiralian) tree of life. Phil Trans R Soc Lond B Biol Sci 2008, 363:1513-1522.

5. Hay $B$, Jan $L Y$, Jan $Y N$ : A protein component of Drosophila polar granules is encoded by vasa and has extensive sequence similarity to ATPdependent helicases. Cell 1988, 55:577-587.

6. Mochizuki K, Nishimiya-Fujisawa C, Fujisawa T: Universal occurrence of the vasa-related genes among metazoans and their germline expression in Hydra. Dev Genes Evol 2001, 211:299-308. 
7. Mahowald AP: Assembly of the Drosophila germ plasm. Int Rev Cytol 2001, 203:187-213.

8. Johnstone O, Lasko P: Interaction with elF5B is essential for Vasa function during development. Development 2004, 131:4167-4178.

9. Johnstone O, Lasko P: Translational regulation and RNA localization in Drosophila oocytes and embryos. Annu Rev Genet 2001, 35:365-406.

10. Tanaka SS, Toyooka $Y$, Akasu R, Katoh-Fukui $Y$, Nakahara $Y$, Suzuki $R$, Yokoyama M, Noce T: The mouse homolog of Drosophila Vasa is required for the development of male germ cells. Genes Dev 2000, 14:841-853.

11. Brown FD, Swalla BJ: Vasa expression in a colonial ascidian, Botrylloides violaceus. Evol Dev 2007, 9:165-177.

12. Carre D, Djediat C, Sardet C: Formation of a large Vasa-positive germ granule and its inheritance by germ cells in the enigmatic Chaetognaths. Development 2002, 129:661-670

13. Castrillon DH, Quade BJ, Wang TY, Quigley C, Crum CP: The human VASA gene is specifically expressed in the germ cell lineage. Proc Natl Acad Sci USA 2000, 97:9585-9590.

14. Fabioux C, Pouvreau S, Le Roux F, Huvet A: The oyster vasa-like gene: a specific marker of the germline in Crassostrea gigas. Biochem Biophys Res Commun 2004, 315:897-904

15. Fabioux C, Corporeau C, Quillien V, Favrel P, Huvet A: In vivo RNA interference in oyster-vasa silencing inhibits germ cell development. FEBS J 2009, 276:2566-2573.

16. Knaut H, Pelegri F, Bohmann K, Schwarz H, Nusslein-Volhard C: Zebrafish vasa RNA but not its protein is a component of the germ plasm and segregates asymmetrically before germline specification. J Cell Biol 2000 149:875-888.

17. Ohashi H, Umeda N, Hirazawa N, Ozaki Y, Miura C, Miura T: Expression of vasa (vas)-related genes in germ cells and specific interference with gene functions by double-stranded RNA in the monogenean Neobenedenia girellae. Int J Parasitol 2007, 37:515-523.

18. Rebscher N, Zelada-Gonzalez F, Banisch TU, Raible F, Arendt D: Vasa unveils a common origin of germ cells and of somatic stem cells from the posterior growth zone in the polychaete Platynereis dumerilii. Dev Biol 2007, 306:599-611.

19. Rosner A, Moiseeva E, Rinkevich Y, Lapidot Z, Rinkevich B: Vasa and the germ line lineage in a colonial urochordate. Dev Biol 2009, 331:113-128.

20. Swartz SZ, Chan XY, Lambert JD: Localization of Vasa mRNA during early cleavage of the snail llyanassa. Dev Genes Evol 2008, 218:107-113.

21. Mochizuki K, Sano H, Kobayashi S, Nishimiya-Fujisawa C, Fujisawa T: Expression and evolutionary conservation of nanos-related genes in Hydra. Dev Genes Evol 2000, 210:591-602.

22. Curtis D, Apfeld J, Lehmann R: nanos is an evolutionarily conserved organizer of anterior-posterior polarity. Development 1995, 121:1899-1910.

23. Dill KK, Seaver EC: Vasa and nanos are coexpressed in somatic and germ line tissue from early embryonic cleavage stages through adulthood in the polychaete Capitella sp. I. Dev Genes Evol 2008, 218:453-463.

24. Kang D, Pilon M, Weisblat DA: Maternal and zygotic expression of a nanos-class gene in the leech Helobdella robusta: primordial germ cells arise from segmental mesoderm. Dev Biol 2002, 245:28-41.

25. Rabinowitz JS, Chan XY, Kingsley EP, Duan Y, Lambert JD: Nanos is required in somatic blast cell lineages in the posterior of a mollusk embryo. Curr Biol 2008, 18:331-336.

26. Bentfeld ME: Studies of oogenesis in rotifer, Asplanchna. 1. Fine structure of female reproductive system. Zeitschrift Zellforschung Mikroskopische Anatomie 1971, 115:165-183.

27. Lechner M: Untersuchungen zur Embryonalentwicklung des Rädertieren Asplanchna girodi de Guerne. Roux's Arch Developmental Biol 1966, 157:117-173.

28. Bentfeld ME: Studies of oogenesis in rotifer, Asplanchna. 2. Oocyte growth and development. Zeitschrift Zellforschung Mikroskopische Anatomie 1971, 115:184-195.

29. Boell LA, Bucher $\mathrm{G}$ : Whole-mount in situ hybridization in the rotifer Brachionus plicatilis representing a basal branch of lophotrochozoans. Dev Genes Evol 2008, 218:445-451.

30. Oyama A, Shimizu T: Transient occurrence of vasa-expressing cells in nongenital segments during embryonic development in the oligochaete annelid Tubifex tubifex. Dev Genes Evol 2007, 217:675-690.

31. Neilsen C: Animal Evolution: Interrelationships of the Living Phyla. Oxford: Oxford University Press, Oxford 2001.
32. Lambert JD: Mesoderm in spiralians: the organizer and the $4 d$ cell. $J$ Exp Zool B Mol Dev Evol 2008, 310:15-23.

33. Habetha M, Bosch TC: Symbiotic Hydra express a plant-like peroxidase gene during oogenesis. J Exp Biol 2005, 208:2157-2165.

34. Lee KP, Simpson SJ, Clissold FJ, Brooks R, Ballard JW, Taylor PW, Soran N, Raubenheimer D: Lifespan and reproduction in Drosophila: New insights from nutritional geometry. Proc Natl Acad Sci USA 2008, 105:2498-2503.

35. Grandison RC, Piper MD, Partridge L: Amino-acid imbalance explains extension of lifespan by dietary restriction in Drosophila. Nature 2009, 462:1061-1064.

36. Guillard RR, Ryther JH: Studies of marine planktonic diatoms. I. Cyclotella nana Hustedt, and Detonula confervacea (cleve) Gran. Can J Microbiol 1962, 8:229-239.

37. Guillard RR: Culture of phytoplankton for feeding marine invertebrates. Culture of Marine Invertebrate Animals New York: Plenum PressSmith MH 1975, 26-60.

38. Chang CC, Dearden P, Akam M: Germ line development in the grasshopper Schistocerca gregaria: vasa as a marker. Dev Biol 2002, 252:100-118

39. Pilon M, Weisblat DA: A nanos homolog in leech. Development 1997 124:1771-1780

40. Denekamp NY, Thorne MA, Clark MS, Kube M, Reinhardt R, Lubzens E: Discovering genes associated with dormancy in the monogonont rotifer Brachionus plicatilis. BMC Genomics 2009, 10:108

41. Suga K, Mark Welch D, Tanaka Y, Sakakura Y, Hagiwara A: Analysis of expressed sequence tags of the cyclically parthenogenetic rotifer Brachionus plicatilis. PLoS One 2007, 2:e671.

42. Huang X, Madan A: CAP3: A DNA sequence assembly program. Genome Res 1999, 9:868-877.

43. Altschul S, Gish W, Miller W, Myers E, Lipman D: Basic local alignment search tool. J Molec Biol 1990, 215:403-410.

44. Thompson JD, Higgins DG, Gibson TJ: CLUSTAL W: improving the sensitivity of progressive multiple sequence alignment through sequence weighting, positions-specific gap penalties and weight matrix choice. Nucleic Acids Res 1994, 22:4673-4680

45. Ronquist F, Huelsenbeck JP: MrBayes 3: Bayesian phylogenetic inference under mixed models. Bioinformatics 2003, 19:1572-1574.

46. Whelan S, Goldman N: A general empirical model of protein evolution derived from multiple protein families using a maximum-likelihood approach. Mol Biol Evol 2001, 18:691-699.

47. Huson DH, Richter DC, Rausch C, Dezulian T, Franz M, Rupp R: Dendroscope: an interactive viewer for large phylogenetic trees. $B M C$ Bioinformatics 2007, 8:460.

48. Osborne P, Dearden PK: Non-radioactive in situ hybridisation to honeybee embryos and ovaries. Apidologie 2005, 36:113-118.

49. Patel NH: Imaging neuronal subsets and other cell types in whole-mount Drosophila embryos and larvae using antibody probes. Drosophila melanogaster.Practical uses in Cell and Molecular Biology London: Academic PressGoldstein LSB, Fyrberg EA , 44 1994, 446-485, [Wilson L, Matsudaira P (Series Editor): Methods in Cell Biology].

doi:10.1186/2041-9139-1-5

Cite this article as: Smith et al:: Germ cell specification and ovary structure in the rotifer Brachionus plicatilis. EvoDevo 2010 1:5.

\section{Submit your next manuscript to BioMed Central and take full advantage of:}

- Convenient online submission

- Thorough peer review

- No space constraints or color figure charges

- Immediate publication on acceptance

- Inclusion in PubMed, CAS, Scopus and Google Scholar

- Research which is freely available for redistribution 